УДК 303.4:316.334.2

DOI https://doi.org/10.32837/apfs.v0i29.965

\author{
O. I. Щерба \\ ORCID ID: https://orcid.org/0000-0003-2475-1696 \\ кандидат соиіологічних наук, доцент, \\ науковий співробітник відділу соиіальної антропологї̈ \\ Інституту народознавства Національної академії наук України
}

\title{
СУСПІЛЬСТВО СПОЖИВАННЯ ТА КОНСЮМЕРИЗМ - НОВІ ТЕНДЕНЦІЇ ТА ВИКЛИКИ ДЛЯ УКРАЇНИ
}

Постановка проблеми. Споживання є ключовим явищем сучасності, категорією, яка є важливою для опису реальності й дає змогу оцінити стан індивідів і суспільства. Це явище впливає на форму соціальної реальності, а також на ідентичність індивіда й спосіб його сприйняття, оскільки він стає насамперед споживачем. Тому споживання - це більше, ніж володіння та використання речей, це спосіб побудови ідентичності людей, а також ідентичності світу товарів, що нас оточує.

Споживання в сучасних суспільствах трактується як одна із центральних цінностей, насамперед завдяки його економічній ролі й місцю в системі соціальних цінностей. Споживання вже не $є$ засобом досягнення мети, а стає метою людської дії. Однак усе частіше виникають питання, пов' язані з інноваційною поведінкою споживачів, яка стає противагою консюмеризму й споживацьким гедоністичним цінностям. Не залишається осторонь цих процесів і Україна. Цим і зумовлена актуальність теми нашої публікації.

Аналіз останніх досліджень і публікацій 3 обраної проблеми. Вивченням проблем суспільства споживання та консюмеризму займалися зарубіжні класики-соціологи. Зокрема, Е. Фромм запропонував своєрідну програму «соціальної реконструкції» індустріального суспільства, вказував на штучні (вигадані) потреби, нав'язані індивіду суспільним виробництвом, на помирання його духовного начала через надмірне споживання та розкіш. Т. Веблен запропонував теорію престижного споживання. Ж. Бодріяр проаналізував суспільство споживання в соціологічному, економічному, політичному й культурологічному вимірі, увівши водночас поняття "симулякру». 3. Бауман обгрунтовує абсолютну керованість споживача в сучасному світі, яка може існувати навіть у випадку відчуття індивідом повної свободи. Дж. Рітцер уводить поняття «макдональдизації» глобального світу, аналізує індустрію фаст-фуду, описує нові засоби споживання. С. Барталем'ю звертає увагу на ряд особливостей консюмеризму, серед яких ключовою вважає свободу вибору товару, стилю життя чи власної ідентичності. Л. Коен виокремлює типи споживача залежно від ролі, яку він виконує в різних сферах суспільного життя. Р. Ботсман і Р. Роджерс вивчали спільне (кооперативне) споживання та розглядали його основні категорії. Сучасні дослідники Е. Кежель, В. Вотроба, А Левицька-Стжалецька, Я. Шмид, С. Ільїних, В. Ільїн, Ч. Бивалець, Л. Рудницький, Ф. Билок, П. Вардак, Т. Залега й інші у своїх наукових працях звертають увагу на нові тенденції в поведінці споживачів, такі як політичний / етичний / екологічний консюмеризм та обмеження споживання. Різні аспекти функціонування сфери споживання вивчали українські соціологи В. Тарасенко, Є. Суїменко, В. Пилипенко, Н. Лисиця, В. Резнік, Т. Петрушина й інші. Критичний підхід до споживання та надмірність у споживанні досліджують українські вчені М. Шульга, В. Мандибура, Я. Зоська, В. Лапіна, В. Торяник. Попри наявність чималої кількості наукових публікацій, дотичних до обраної проблематики, не досить уваги приділено вивченню нових тенденцій, пов'язаних із протидією консюмеризму, та їхньому прояву в поведінці українських споживачів.

Метою статті $€$ виявлення нових тенденцій споживання як альтернативи надмірному споживанню, аналіз їхнього розвитку в українському суспільстві.

Виклад основного матеріалу. Реалізуючи мету дослідження, насамперед визначимо основні поняття нашої публікації. Підкреслимо, що поняття «суспільство споживання» $€$ одним із базових у теорії споживання та походить ще від ідеї К. Маркса про «товарний фетишизм», описаний ним у «Капіталі». Кардинальні зміни у сфері споживання пов'язують із Генрі Фордом і створеним ним новим типом промислового виробництва, який згодом отримав назву «фордизм». Нововведення базувалися на впровадженому геніальним підприємцем на своїх заводах конвеєру, високих заробітних платах робітників, залученні до праці людей з інвалідністю та низьких цінах на продукцію. 3 того часу виробництво стає масовим, а споживати мають змогу не лише найбагатші, а й усі верстви населення.

Термін «суспільство споживання» вперше ввів у науковий лексикон Е. Фромм у своїй книзі «Мати чи бути». Учений визначав його як суспільні 
відносини, що базуються на принципі індивідуального споживання, де багато людей вважають найбільш прийнятним способом життя постійне придбання та прагнення до володіння речами [1]. Але пройшло півстоліття, поки 3 появою книги Ж. Бодріяра «Суспільство споживання. Його міфи й структури» [2] термін міцно ввійшов у словник суспільних наук. Учений характеризував таке суспільство як простір надмірного споживання, в якому індивіди не лише задовольняють свої наявні потреби, але й потреби, створені штучно новою панівною гедоністичною ідеологією.

Т. Веблен є одним із творців соціологічної теорії споживання. Він підкреслював, що метою придбання речі в суспільстві споживання $\epsilon$ не стільки задоволення природних потреб, скільки демонстрація приналежності індивіда до того чи іншого класу. У своїй книзі «Теорія бездіяльного класу» [3] він уводить поняття «демонстративне споживання», яке нині активно використовують дослідники обраної проблеми. Демонстративне (престижне, показне, статусне) споживання - це марнотратні витрати на товари й послуги, основною метою яких є демонстрація власного багатства.

Окрім того, як зазначає Т. Веблен, «для пана, який живе дозвіллям, демонстративне споживання матеріальних цінностей є засобом досягнення поваги. Відповідно до того, як багатство зосереджується в його руках, його власні зусилля не забезпечать йому доказів своєї могутності без сторонньої допомоги. Тому він кличе на допомогу друзів і суперників, даруючи цінні подарунки й влаштовуючи дорогі бенкети й розваги. Подарунки й бенкети, ймовірно, мали інше походження, ніж наївні хвастощі, але зручну можливість їхнього використання саме із цією метою вони придбали дуже рано, зберігаючи за собою вказану властивість дотепер» [3, с. 60]. Отже, запрошені гості здійснюють замість господаря підставне споживання та разом із тим є свідками споживання цих надлишкових благ, якими господар не в змозі розпорядитися без їхньої допомоги.

3 середини XX ст. суспільства розвинених країн зазнали інтенсивних змін у поведінці споживачів. Це зміни відбувалися в межах ієрархії потреб, рівня, засобів і способів їхнього задоволення, а також критеріїв здійснення споживчих виборів. Їхнім проявом є також поширення споживання нових товарів. На макросоціальному рівні це означає, серед іншого, збільшення ролі споживання, що стало віссю суспільного життя та зв'язку, що інтегрує індивідів. Споживання не лише забезпечує відчуття задоволення, а також дозволяе змінити сприйняття споживачами навколишньої реальності й власної ідентичності [4, с. 179$]$.

Консюмеризм стає специфічним способом життя, який пов' язаний із надмірною купівлею та споживанням товарів. Характерною схемою поведінки є шопінг (shopping), що розуміється двояко: 1) як здійснення спонтанних покупок у торгових центрах та 2) як форма чуттєвого споживання, пов'язана з розгляданням вітрин і товарів у магазинах без мотивації їх купити.

Згідно із 3. Бауманом, зараз ми можемо спостерігати перехід від епохи виробництва, заснованої на трудовій етиці, до епохи споживання, заснованої на естетиці споживання. Виконання обов'язків було замінено потребою в споживчому досвіді. У сучасному суспільстві робота стала для індивіда способом здобування коштів для того, щоб отримати можливість піддаватися спокусам споживання, отримувати щоразу нові «враження», вдаватися до постійного пошуку й творення «себе» [5]. Споживання - це діяльність, завдяки якій індивід формує власний імідж, досягає цілі, реалізує сповідувані цінності через поведінку споживача. Тепер саме споживча діяльність (а не професійна) є основною сферою самовираження та самореалізації для особистості.

Як зазначає український соціолог М. Шульга, «в кожну епоху існує центральна сфера життєдіяльності, визнана суспільством провідною в життєдіяльності особистості, яка в певному сенсі підпорядковує, підлаштовує під себе всі інші сфери. Так, у середньовіччі й у феодальних суспільствах такою була релігійна сфера, в новітній час і в індустріальних суспільствах - це трудова сфера діяльності. У сучасних розвинених суспільствах провідною сферою стало споживання. <..> Історично часова структура особистості істотно змінюється. У людини в середньовіччі значна частина часу в їі добовому балансі йшла на молитви, відвідування церкви. <..> Центральним сегментом у структурі часу життя сучасної людини є сегмент, пов'язаний зі споживанням» [6, с. 265].

Центральне місце споживання в житті сучасного суспільства описує у своїй праці Ж⿱ Бодріяр, який називає присвячений цьому параграф «Споживання споживання»: «<...> Достаток і споживання - підкреслимо ще раз, не достаток і споживання матеріальних благ, виробів і послуг, а спожитий образ споживання - формує саме нашу нову родову міфологію, мораль сучасності. Та обставина, що суспільство сприймає себе як суспільство споживання, має бути вихідним пунктом об’єктивного аналізу» [2, с. 165-166].

Отже, в сучасному суспільстві найважливішою метою для людини стає споживання. Ідеологія консюмеризму формує проспоживацьке ставлення до всіх процесів, які відбуваються в суспільстві (як у високорозвинених державах, так і в країнах, що розвиваються). 3 'явившись разом із глобальною культурою, вона стає одним із найважливіших факторів, що провокують зміни в суспільному житті. 
Необхідно зазначити, що в українській науковій літературі такі поняття, як «суспільство споживання», «консюмеризм» $\mathrm{i}$ «споживацтво» використовуються як синоніми, із чим ми не погоджуємося, оскільки ці поняття, хоча й схожі за значеннями, мають відмінності у своєму змісті. Розглянемо кожне поняття окремо.

Українська дослідниця В. Лапіна проаналізувала інтерпретації поняття «суспільство споживання», які існують в новітній теоретичній соціології, та розглядає його як:

1) універсальний онтологічний прототип індустріального капіталістичного суспільства як локальної соціально-історичної системи;

2) специфічний онтологічний тип розвинутої частини світової капіталістичної системи;

3) окрему новітню фазу глобального історичного розвитку постіндустріальних (інформаційних) соціумів, в якому сфера споживання є провідною.

Водночас переважна більшість соціологів схильна вважати, що найважливішим атрибутивним і наочним проявом суспільства споживання $е$ консюмеризм [7, с. 41]. Отже, поняття «консюмеризм» $€$ вужчим і не тотожним поняттю «суспільство споживання», а відповідний йому феномен $є$ найхарактернішою рисою суспільства споживання.

1) Дослідник В. Вонтроба також визначає консюмеризм як одну з важливих характеристик суспільства споживання та описує його як:

1) спосіб життя, що забезпечує прояв актів споживання в культурній сфері;

2) атрибут сучасної ідентичності людини;

3) соціально-психологічне явище або форму залежності від матеріальних благ і послуг [8, c. 166-167].

Отже, консюмеризм є соціальним явищем у межах певного суспільства й специфічним способом життя сучасної людини.

Однак в українській науковій думці існують і інші визначення поняття консюмеризму. Український вчений В. Мандибура, узагальнюючи різні дефініції поняття, тлумачить консюмеризм як:

1) систему суспільних відносин, що пов'язані й виникають у процесі організованого соціального руху громадян, мають адекватну цьому руху регулювальну діяльність державних інститутів (установ, організацій) і нормативно-правової системи, спрямовані на захист інтересів споживачів, передусім у сфері розширення прав і посилення впливу покупців на виробників і продавців товарів (послуг);

2) соціально-економічні механізми, що на суспільному рівні гарантують реалізацію права людини споживати якісні й безпечні товари й послуги, які вона отримує в процесі ринкового обміну (у фірм-виробників, спеціалізованих продавців і в приватних осіб, що мають право на виробництво й торгівлю товарами масового попиту);

3) гарантоване державою право щодо забезпечення реальної можливості громадянам створювати спілки, які метою своєї діяльності мають захист прав та інтересів споживачів [9, с. 60].

Внесемо уточнення щодо останніх тлумачень поняття «консюмеризм». Пропонуємо називати рух, спрямований на захист прав споживачів, політичним консюмеризмом, як це заведено в зарубіжній соціології. Це дало б змогу уникнути двозначностей, плутанини понять і неправильного подвійного тлумачення такого феномену.

Споживацтво ми розуміємо як прагнення тільки до задоволення власних потреб, споживацьке ставлення до чогось. Можна вважати його крайнім проявом консюмеризму.

Українські соціологи Я. Зоська й Б. Сторчовий зазначають, що споживацтво є викривленою абсолютизацією позитивних інтенцій споживання, а його основні симптоми є наслідком реалізації таких цінностей споживання: збільшення багатства, слава й успіх, спрямованість на себе, наслідування моди, постійні нові придбання, прагнення змін і зростання. Синдром споживацтва визначається такими ознаками споживчої свідомості, як: бажання постійно купувати новий одяг і часто змінювати його; прагнення мати речі, які вражають інших людей; намагання отримувати задоволення та поліпшувати настрій шляхом придбання речей і розуміння наявності зайвих речей, яких шкода позбавитися [10, с. 114-115]. Загалом споживацька поведінка в суспільстві набуває статусу соціальних практик споживання як стійких сукупностей дій, що становлять зміст соціальної системи.

Отже, поряд із розвитком масової культури, прогресивним процесом глобалізації відбулися зміни в моделях споживання, моді й смаках споживачів. Таким чином, була створена нова модель трактування споживання як самоцілі, а не лише як способу задоволення людських потреб. Ми можемо побачити це в об'єднаних механізмах поведінки споживачів і зміні їхнього способу життя. У повсякденній життєвій практиці ми маємо справу з надмірним споживанням. Консюмеризм не рахується з індивідуальними, соціальними чи глобальними витратами. 3'являються все нові форми консюмеризму, серед них оніоманія (шопоголізм), інфантилізація споживачів, тенденція «тут і зараз», гедонізм та утилітаризм. Як зазначає Дж. Рітцер [11], консюмеризм стає своєрідною новою релігією, а торгові центри - це місця, де відбувається безперервний спектакль споживання.

Дослідник С. Барталем'ю виокремлює певні особливості консюмеризму. По-перше, вказує на культуру споживання як основу консюмеризму, 
в якій цінності пов'язані зі споживанням. По-друге, підкреслює, що консюмеризм є індивідуальним вибором. Свобода вибору товару, стилю життя чи власної ідентичності - це обов'язкове правило в сучасному суспільстві споживання. По-трете, споживча культура створює потреби як необмежені й водночас ненаситні $[12$, с. 6-9]. Консюмеризм пропонує способи задоволення потреб, але постійно з'являються нові, що викликає почуття незадоволення та змушує споживачів шукати щоразу нові споживчі товари.

Дослідник Я. Шмид пропонує ввести до наукового обігу поняття «споживче життя». Під ним він розуміє повсякденний спосіб життя, який домінує в суспільстві, що споживає; новий, історично безпрецедентний тип людського існування, характерний лише для епохи постмодернізму, асимільований і практикований більшістю людей, що належать до сучасних економічно й технологічно високорозвинених «ринкових» i «технократичних" суспільств; завдяки домінівному в таких суспільствах типу повсякденного споживчого стилю їх ще називають «суспільствами споживання». «Споживче життя» - це реальний соціально-економічний, ментально усвідомлений, психокультурний і життєво-поведінковий факт, який відрізняє ці суспільства від інших і є однією з їхніх найважливіших характерних рис. <...> Саме поняття включає насамперед специфічний зміст і менталітет, соціальну й індивідуальну обізнаність, особистість, індивідуальну культуру, поведінку й життєву активність людини в епоху «постмодернізму» й глобальної ринкової системи («гіперкапіталізму») [13, с. 23].

Тож ми маємо справу не лише 3 певною соціальною, економічною та культурною категорією, але також (а можливо й насамперед) з антропологічним поняттям, у певному розумінні з категорією аксіологічною, етичною, естетичною та педагогічною, а також із характерним критерієм оцінки якості людського існування, духовного й культурного стану людей і спільнот.

Зазначимо, що сучасна споживча культура базується на культі новизни й гаджетизації. Життєвий цикл товару стає все коротшим, новітні моделі витісняють старі за дуже короткий проміжок часу. Формується враження, що немає товарів тривалого користування, які могли б довго служити людині.

Щоб зрозуміти суть суспільства споживання, необхідно побачити два важливих моменти [14, с. 30]: по-перше, споживання починає відігравати переважальну роль у соціальних відносинах, що приводить до зміни цих відносин. По-друге, домінівним у розумінні споживання $е$ не економічний, а соціальний і культурний підхід. Іншими словами, суспільство споживання (на відміну від «суспільства як такого») виводить спо- живання за рамки економічної сфери, за рамки споживання як матеріального, утилітарного процесу із задоволення індивідом своїх потреб, а саме в соціокультурну сферу.

У споживачів формується відповідний хабітус як результат їхньої діяльності споживання. Відповідно до цього хабітуса об'єктивно класифікується вся практика, продукується певний вид практики (споживчий), класифікуються навколишні предмети, факти, оцінюються різні продукти й практики. Habitus споживача захищає себе від криз і критичних нападів, забезпечуючи собі настільки, наскільки це можливо, середовище, до якого він уже пристосований, тобто відносно постійне коло ситуацій, що підсилює його схильності, забезпечуючи ринок, найдоречніший для його продуктів. Найпарадоксальніша властивість habitus'a - це те, що індивідом відбирається інформація, необхідна для того, щоб ухилитися від інформації. Саме тому ідентичність споживача, сформована в ситуації ухилення від якої б то не було рефлексії, $є$ розмитою та не цілком цілісною [14, с. 34].

Отже, важливим елементом способу життя, заснованого на постійному споживанні нових товарів, є використання споживання для створення індивідуальної ідентичності. До того ж така ідентичність не виражається однією формою, а виникає в багатьох різних варіаціях, між якими немає принципових відмінностей. Індивід може вільно обирати різні ідентичності залежно від соціальної ситуації. Тому можемо говорити про певну плинність ідентичності.

В. Ільїн $[15$, с. 43$]$ вважає, що на новому етапі розвитку суспільства споживання з'являється новий вид консюмеризму - креативний консюмеризм. Він стає можливим завдяки наявності цілого ряду передумов, які, з одного боку, роблять такий консюмеризм технічно й економічно можливим, а з іншого, - породжують масову потребу в ньому. По-перше, зміни в організації виробництва: а) наявна тенденція переходу від конвеєрного виробництва до гнучких технологій (тобто від фордизму до постфордизму). Вона створює можливість підтримувати споживання в умовах перевиробництва, спираючись на тенденцію до диверсифікації смаку, на прагненні до конструювання індивідуальності; б) через різні причини формується тенденція до залучення споживачів в індивідуальне виробництво, що є доповненням до товарів і послуг, які купуються (наприклад, перероблення товару відповідно до власного смаку споживача). По-друге, загострення суперечності між, з одного боку, тенденцією до тотальної раціоналізації та деградації сфери праці, й з іншого, - стимульованою зростанням рівня освіти революцією творчих домагань, що проявляються в бажанні людини реалізувати свій творчий хист. 
Узагальнюючи, ми можемо стверджувати, що натепер ми маємо справу з явищем надмірного споживання, яке призводить до марнотратства вироблених товарів (надвиробництва), деградації природного середовища, наростання диспропорцій у суспільстві на локальному й глобальному рівнях, поступового знищення невідновлюваних природних ресурсів та інших несприятливих явищ. Незважаючи на те, що споживання є атрибутом сучасної високорозвиненої цивілізації, а покупець товарів і послуг є ключовою фігурою конкурентоспроможної економіки, споживчі організації та рухи все частіше вживають заходів, які мають на меті обмежити негативні явища, джерелом яких є надмірне споживання. Завдяки цій діяльності з'явилися нові тенденції в поведінці покупців товарів і послуг, які є противагою явищу надмірного споживання, в тому числі такі як: (1) політичний консюмеризм, про який вже згадувалось, (2) етичний консюмеризм, (3) екологічний консюмеризм, (4) дематеріалізація споживання, (5) обмеження споживання, (6) спільне споживання та (7) споживчі бойкоти.

Розглянемо такі тенденції детальніше, а також виявимо їхнє (не)поширення в Україні.

(1) Дослідниця А. Левицька-Стжалецька тлумачить політичний консюмеризм [16, с. 163] як соціальний рух, що має на меті захист споживачів від наслідків дій підприємств, спрямованих на максимізацію прибутку, а також як широкодоступну освіту, завданням якої є інформування споживачів про їхні права, про фактичну вартість товарів і послуг, безпеку й способи виробництва й використання, рівня якості, ціну тощо. Його основна мета - збереження балансу між виробниками, державою та покупцями. Він поєднує в собі різні тенденції, починаючи від допомоги клієнтам у здійсненні раціональних комерційних операцій і боротьбі з несумлінною конкуренцією до реформаційних рухів, що ставлять під сумнів споживчу природу сучасної цивілізації, моделей споживання та способу життя та виступають із вимогами посилити участь громадян у прийнятті економічних рішень.

Важливість такого руху полягає в тому, що згідно з Л. Коеном нині все більше підкреслюється співіснування двох різних ролей споживача в економічній і політичній сфері: споживач-покупець (purchaser consumer) i споживач-громадянин (citizen consumer). Ця концепція не нова, оскільки ці ролі визначались дослідниками ще на межі XIX-XX ст. [17, с. 205].

Споживачі-покупці повною мірою користуються пропозиціями вільного ринку, тоді як споживачі-громадяни вживають дії на захист своєї групи (боротьба за визнання прав споживачів), а також на захист широкої громадськості. Таким чином, громадяни-споживачі здійснюють знач- ний вплив на політичні реформи, наприклад, справедливу систему оподаткування, захист споживачів від обману, на антимонопольне законодавство, на право громади на суспільні блага, етичне споживання, споживчу освіту в школах.

Такий рух не оминув Україну, проте в більшості випадків український споживач може бути лише тою чи іншою мірою захищеним на внутрішньому споживчому ринку. Щодо глобального ринку, то там він зовсім не захищений (причиною переважно є політичні аспекти й слабкість держави у відстоюванні прав своїх громадян на світовій арені).

(2) Етичний консюмеризм - одна 3 моделей споживчої поведінки, яка базується на певних етичних переконаннях (наприклад, проти тестування косметичної продукції на тваринах або проти порушення прав людини тощо). Етичний консюмеризм передбачає, що виробник гарантує споживачам етичну чистоту власної продукції, поведінки своєї компанії та «наслідків» виробництва продукції та використання продукту. Саме в такому трактуванні етичний консюмеризм починає істотно впливати на сучасний соціум, виконуючи функції соціального контролю у сфері споживчої поведінки й формуючи нові його стандарти навіть на рівні законодавства (виробники зобов'язані вказувати всі складники своєї продукції на кожній упаковці; в деяких країнах заборонене тестування товарів косметичної індустрії на тваринах і тому подібне) [18, с. 72].

Останніми роками навіть у країнах, далеких від демократії, під тиском світової спільноти вводять заборону на споживання таких «традиційних» для них блюд як, для прикладу, блюда із собак. У більшості країн Свропи заборонений гаваж (процес примусового годування птахів), виробництво фуа-гри заборонено в більшості країн ЄС, Аргентині й багатьох штатах США. В Україні прийнято закон «Про захист тварин від жорстокого поводження», який серед іншого забороняє під час технології отримання від тварини продукції (доїння, стрижка, відгодівля тощо) застосування больових і травмувальних прийомів; у 2019 р. був прийнятий закон, який забороняє використання тварин у цирковому мистецтві, а в січні 2020 р. у Верховній Раді України зареєстровано законопроєкт про заборону фуа-гра.

(3) Схожим до етичного консюмеризму є екологічний консюмеризм. Екологічний консюмеризм це елемент руху споживачів, пов' язаний з екоспоживанням, метою якого є боротьба з негативними процесами, що погіршують природне середовище, а отже, якість життя людини, зумовлюючи зміни у сфері споживання. Цей рух постулює зміни, які мають набути форми раціонального використання споживчих товарів: прийняття моделі поведінки, що відповідає принципам охорони довкілля; 
споживання органічних товарів (переважно харчових продуктів); обмеження споживання товарів, які створюють небезпечні відходи після споживання; надавання в споживанні переваги товарам, які «виробляють» невелику кількість відходів після споживання; зменшення використання ресурсів та енергї̈ для виробництва споживчих товарів і мінімізація використання природних ресурсів за допомогою використання чистих способів виробництва [19, с. 224-228].

В Україні такий рух також популярний, але майже абсолютно недієвий, такий, що не досягає своєї мети. Причиною цього є незрілість українського громадянського суспільства. Переважно дії руху спрямовані проти безконтрольного вирубування карпатських лісів, законодавчо забороненого спалення сухого листя / трави й запобігання викидів шкідливих відходів виробництв у річки / озера / моря.

(4) Варто відзначити тенденцію, яка останнім часом сильно посилилася, - це дематеріалізація споживання. Сучасні споживачі все більше переорієнтовуються на споживання таких нематеріальних цінностей, як знання, інформація, освіта й культура. Поряд із фокусуванням на таких цінностях зростає попит на послуги в цих сферах. Можна помітити, що дедалі частіше споживач, що здійснює покупки, вибирає певний товар, керуючись його символічною цінністю. Це новий постмодерністський вимір споживання.

Така тенденція не характерна для України, де, на жаль, можна спостерігати протилежну тенденцію: знецінення освіти й зниження її якості, за рідкісними винятками погана наповненість новинками бібліотек, відсутність у наших співвітчизників зацікавлення до відвідувань бібліотек, а також музеїв. Лише популярність (серед певного сегмента споживачів) театрів, концертів і кіно є відносно стабільною.

(5) Ще одне явище, яке спостерігається в поведінці споживачів протягом останніх років, особливо у високорозвинених країнах, - це свідоме обмеження в споживанні. У цих країнах споживання є невіддільною складовою частиною економіки, яка функціонує в умовах значного перевиробництва товарів. 3 огляду на це видається, що ніяке погіршення матеріального становища або перенасичення споживанням не змусить людину відмовитися від задоволення споживати. Однак зазначена тенденція свідчить про протилежне.

Можна відзначити чотири основні фактори, що визначають феномен свідомого обмеження в споживанні: 1) зменшення споживання через збільшення невизначеності становища сучасних домогосподарств (перестраховувальне споживання), 2) кількісне зменшення споживання з метою зростання бажання якості, 3) скорочення споживання в матеріальній сфері на користь нематері- альної, 4) обмеження споживання для його раціоналізації [20, с. 140-141].

В Україні ця тенденція чітко виражена. Її причиною (в більшості випадків) є перша із зазначених. Як підкреслює М. Шульга у своїй праці «Збій соціальної матриці», "українське суспільство ще не стало в повному розумінні суспільством споживання. Стати таким йому заважає глибока бідність. Однак, незважаючи на бідність, населення орієнтується на консюмеристські цінності й приймає їх" [21, с. 88].

(6) Тенденцією, схожою до обмеження в споживанні, є спільне споживання (collaborative consumption), яке іноді називають «спільною економікою» або «економікою спільної участі» (sharing economy).

Спільне споживання - це економічна модель, яка базується на спільному використанні, обміні й платному наданні в користування ресурсів i товарів. Це зменшує особисте споживання та придбання непотрібних товарів, а також поглиблює інтеграцію та зміцнює суспільні відносини.

Дослідники П. Вардак і Т. Залега [22, с. 9] вказують на те, що спільне (кооперативне) споживання базується на обміні, позиченні, бартері, безплатному або платному наданні своїх благ іншим індивідам. Це нова тенденція, яка знаходиться в опозиції до потреби у власності. Спільне споживання базується на ідеї спільного використання функцій продукту без необхідності володіння ним.

Р. Ботсман і Р. Роджерс [23] виділили три основні категорії спільного споживання, а саме: 1) перерозподільчі ринки (обмін один з одним неновими речами); 2) системи обслуговування товарів (надання товарів людям за певну плату); 3) спільний спосіб життя (collaborative lifestyle), тобто отримання нематеріальних благ від споживання.

В Україні такий спосіб протидії консюмеризму надзвичайно популярний через знову ж таки надто низьку платоспроможність населення. Мають великий попит інтернет-сайти для обміну товарами, купівлі вживаних товарів або можливості отримати річ, послугу, домашню тварину безплатно.

(7) Споживчі бойкоти розглядають як ненасильницький метод протесту, що застосовується для розв'язання різних соціальних і політичних проблем. Споживчий бойкот як спроба однієї або більше сторін досягти певних цілей, переконуючи окремих споживачів утриматися від здійснення покупок на ринку, поділяється на дві великі групи: орієнтовані на ринок (розв' язують здебільшого економічні питання) та орієнтовані на ЗМI (політичні питання) [24, с. 147].

До наймасовіших бойкотів в Україні ми можемо віднести постійний бойкот товарів i послуг, які вироблені або фінансуються з Російської Федерації (далі - РФ). Після окупації РФ 
Кримського півострова й початку війни на Донбасі українські активісти почали кампанію проти придбання російських товарів під гаслом: «Купуєш російське - фінансуєш тероризм». 3 січня 2016 p. Україна запровадила ембарго на велику кількість російських продовольчих товарів, магазини зобов'язали маркувати продукцію, вироблену в РФ; була введена заборона (яка нещодавно законодавчо подовжена) на користування російськими соціальними мережами.

Говорячи про надлишкове споживання в Україні, необхідно виокремити ще одну непопулярну для високорозвинених суспільств, проте властиву нашій державі функцію. Споживання стало для українців механізмом компенсації всіх недоотриманих ними товарів і послуг, яких постійно не вистачало в період тотального товарного дефіциту, що тривав протягом десятків років перебування в СРСР. Тепер, коли з'явилася можливість задоволення практично будь-яких матеріальних благ, почуття міри в українців почало зраджувати.

Висновки. Отже, в результаті дослідження розмежовано поняття «суспільство споживання», «консюмеризм», «споживацтво». Запропоновано називати рух, спрямований на захист прав споживачів, «політичним консюмеризмом» (а не «консюмеризмом» загалом, як це є натепер), як це заведено в зарубіжній соціології. Це дає змогу уникнути двозначностей, плутанини понять i неправильного подвійного тлумачення такого феномену.

Поняття «споживацтво» запропоновано розуміти як прагнення лише до задоволення власних потреб, споживацьке ставлення до чогось. Вважаємо його крайнім проявом консюмеризму, але не тотожним такому поняттю.

Стверджуємо, що натепер ми маємо справу 3 явищем надмірного споживання, яке призводить до марнотратства вироблених товарів (надвиробництва), деградації природного середовища, наростання диспропорцій у суспільстві на локальному й глобальному рівнях, поступового знищення невідновлюваних природних ресурсів та інших несприятливих явищ. Однак зазначається, що споживання також є атрибутом сучасної високорозвиненої цивілізації, а споживач $\epsilon$ ключовою фігурою конкурентоспроможної економіки. Завдяки методу критичного аналізу вітчизняних і зарубіжних праць виокремлено різні альтернативні форми споживчої поведінки, які обмежують вплив ідеології споживацтва на споживчі рішення. Представлені й проаналізовані, в тому числі й на прикладі України, вибрані рухи проти консюмеризму (політичний консюмеризм, етичний консюмеризм, екологічний консюмеризм). Показано зростальне значення в українському суспільстві моделей поведінки, пов'язаних зі зменшенням споживання (дематеріалізація споживання, обмеження споживання, спільне споживання та споживчі бойкоти).

У подальших публікаціях маємо на меті звернутись до аналізу нової тенденції в споживанні домоцентризму та його впливу на споживче життя українців.

\section{Jimepamypa}

1. Фромм Э. Иметь или быть. Москва : Астрель, 2010. $320 \mathrm{c}$.

2. Бодрийяр Ж. Общество потребления. Его мифы и структуры / пер. с фр. Е.А. Самарской. Москва : Культурная революция, Республика, 2006. 269 с.

3. Веблен Т. Теория праздного класса / пер. с англ. С.Г. Сорокиной. Москва : Прогресс, 1984. 368 с.

4. Konsument i jego zachowania na rynku europejskim / red. E. Kieżel. Warszawa : PWE, 2010. 308 s.

5. Bauman Z. Praca, konsumpcjonizm i nowi ubodzy / Tłum. S. Obirek. Kraków : WAM, 2006. $212 \mathrm{~s}$.

6. Шульга Н.О. Дрейф на обочину. Двадцать лет общественных изменений в Украине. Киев : ТОВ «Друкарня Бізнесполіграф», 2011. 448 с.

7. Лапіна В.В. Концептуальні інтерпретації феномена консьюмеризму в новітній соціології: теоретичний та методичний аспекти. Актуальні проблеми соиіологї̈, психології, педагогіки. 2014. № 1 (22). С. 37-42.

8. Wątroba W. Społeczeństwo konsumpcyjne w dobie globalizacji. Wrocław : Wydawnictwo Akademii Ekonomicznej we Wrocławiu, 2006. $255 \mathrm{~s}$.

9. Мандибура В.О. Відновлення довіри суб'єктів кінцевого споживання як складова соціальної відповідальності бізнесу. Теоретичні та прикладні питання економіки. Збірник наукових пращь. Випуск 21. Київ : Видавничо-поліграфічний центр «Київський університет», 2010. С. 55-68.

10. Зоська Я.В., Сторчовий Б.А. Споживацтво українців: вільний час та практики його споживання. Соиіальні технології: актуальні проблеми теорії та практики. 2015. Вип. 67-68. С. 113-122.

11. Ritzer G. Magiczny świat konsumpcji. Warszawa : Warszawskie Wydawnictwo Literackie MUZA S.A., 2004. $354 \mathrm{~s}$.

12. Bartholomew C. Christ and Consumerism: An Introduction. Christ and Consumerism. Critical reflections on the spirit of our age / Edited by C. Bartholomew, T. Moritz. Paternoster Publishing, Carlisle, 1988. $177 \mathrm{p}$.

13. Szmyd J. Nowoczesny konsumpcjonizm - zmiana kondycji ludzkiej i jakości życia. Wyzwania społeczne i pedagogiczne. Kultura - Przemiany-Edukacja. 2017. T. V.S. $13-36$.

14.Ильиных С.А. Ключевые понятия общества потребления: исследование с позиции социологии. Журнал соииологии и социальной антропологии. 2011. Tом XIV. № 5 (58). C. 29-40.

15.Ильин В.И. Креативный консюмеризм как тренд современного общества потребления. Журнал социологии и социальной антропологии. 2011. T. XIV. № 5(58). C. 41-54.

16. Edukacja konsumenta. Cele, instrumenty, dobre praktyki / red. A. Lewicka-Strzałecka. Warszawa : Wydawnictwo WSPiZ, 2006. $254 \mathrm{~s}$. 
17. Cohen L. Citizen Consumers in the United States in the century of mass consumption. The Politics of Consumption: Material Culture and Citizenship in Europe and America / Edit. by M. Daunton, M. Hilton. New York, Berg, 2001. 310 p.

18. Троцук И.В., Давыденкова Е.С. Феномен этического консьюмеризма: специфика социологической интерпретации и особенности современного бытования. Вестник РУДН. Серия Социология. 2015. № 1. C. 65-81.

19. Bylok F. Konsumpcja, konsument i społeczeństwo konsumpcyjne we współczesnym świecie. Katowice : Wyd. Naukowe „Sląsk”, 2013. 266 s.

20. Bywalec Cz., Rudnicki L. Konsumpcja. Warszawa : PWE, 2002. $272 \mathrm{~s}$.

21.Шульга М.О. Збій соціальної матриці. Київ : Інститут соціології НАН України, 2018. 284 с.

22. Wardak P., Zalega T. Konsumpcja kolaboratywna jako nowy trend konsumencki. Studia i Materiały. Wydzial Zarzadzania. Uniwersytet Warszawski. 2013. 16. Nr. 1. S. 7-32.

23. Botsman R., Rogers R. What's Mine Is Yours: The Rise of Collaborative Consumption. Harper Collins, New York, 2010. $304 \mathrm{p}$.

24. Торяник В.М. Споживчий бойкот як інструмент політичного консумеризму. «Грані» Науково-теоретичний $і$ гроладсько-політичний альланах. № 4 (78). Липень-серпень 2011. С. 144-148.

\section{Анотація}

Щерба O. I. Суспільство споживання та консюмеризм - нові тенденції та виклики для України. Стаття.

У статті розкривається зміст феноменів суспільства споживання, консюмеризму й споживацтва, а також відповідних ним понять. Виокремлюються нові тенденції споживання, які є противагою явищу надмірного споживання, здійснюється аналіз їхнього розвитку в українському суспільстві. Розглядається науковий доробок з обраної автором проблематики, зокрема роботи таких класиків соціології, як Е. Фромм, Т. Веблен, Жћ. Бодрійяр, 3. Бауман, Дж. Рітцер та інші, а також таких сучасних дослідників, як Е. Кежель, В. Ватроба, Я. Шмид, С. Ільїних, В. Ільїн, Ф. Билок та інші, в тому числі сучасних українських учених М. Шульги, В. Мандибури, Я. Зоськи, В. Лапіної, В. Торяника. Наголошується на тому, що поряд із розвитком масової культури, прогресом глобалізації відбулися зміни в моделях споживання, моді й смаках споживачів. Зазначається, що таким чином була створена нова модель трактування споживання як самоцілі, а не лише як способу задоволення людських потреб. Підкреслюється, що в сучасному суспільстві найважливішою метою людини стає споживання, воно використовується для створення індивідуальної ідентичності. Здійснюється теоретичне розмежування змісту таких понять, як «суспільство споживання», «консюмеризм», «споживацтво», «споживче життя», «креативний консюмеризм». Обгрунтовується, що поняття «консюмеризм» вужче, ніж поняття «суспільство споживання», що феномен консюмеризму є найхарактернішою рисою суспільства споживання. Наго- лошується на тому, що рух, спрямований на захист прав споживачів, є політичним консюмеризмом, як це визнано в зарубіжній соціології. Аналізуються нові тенденції в поведінці покупців товарів і послуг, що $є$ противагою явищу надмірного споживання, а саме: політичний консюмеризм, етичний консюмеризм, екологічний консюмеризм, дематеріалізація споживання, обмеження споживання, спільне споживання та споживчі бойкоти. Доводиться зростальне значення в українському суспільстві моделей поведінки, пов'язаних зі зменшенням споживання.

Ключові слова: суспільство споживання, консюмеризм, споживацтво, політичний консюмеризм, етичний консюмеризм, екологічний консюмеризм, дематеріалізація споживання, обмеження споживання, спільне споживання, споживчі бойкоти.

\section{Summary}

Shcherba O. I. Consumption society and consumerism - new trends and challenges for Ukraine. - Article.

The goal of the article is to reveal and analyze the concepts of "consumer society", "consumerism" and 'consumption'; identification of new trends in consumption, which are a counterbalance to the phenomenon of excessive consumption, as well as analysis of their development in Ukrainian society. The article reviews the given problems in researches of classics of sociology, such as E. Fromm, T. Veblen, J. Baudrillard, Z. Bauman, J. Ritzer, etc., modern researchers of sociologists E. Kiezel, V. Watroba, J. Szmyd, S. Ilyinyh, V. Ilyin, F. Bylok, etc., as well as modern Ukrainian scientists M. Shulga, V. Mandybura, J. Zoska, V. Lapina, V. Toryanyk. It is emphasized that along with the development of mass culture, the advancing of the globalization process, the changes in consumer patterns, fashion and consumer tastes have occurred. It is noted that in this way, a new model of interpretation of consumption as a goal in itself was created, and not only as a way to meet human needs. It is proved that in modern society consumption is the most important goal for a person. It is emphasized that consumption is used to create an individual identity. Theoretical bases of justification, delimitation and interpretation of the concepts "consumer society", "consumerism", "consumption", "consumer life", "creative consumerism" are given. It is justified that "consumerism" is narrower and not identical to the concept of "consumer society" and is its most characteristic feature. It is proposed to call the movement aimed at protecting consumer rights political consumerism, as it is accepted in foreign sociology. New trends in the behavior of buyers of goods and services that counterbalance the phenomenon of excessive consumption are analyzed, such as: political consumerism, ethical consumerism, eco (green) consumerism, dematerialization of consumption, restriction of consumption, collaborative consumption and consumer boycotts. The growing importance of patterns of behavior associated with decreasing consumption in Ukrainian society is shown.

Key words: consumer society, consumerism, consumption, political consumerism, ethical consumerism, eco (green) consumerism, dematerialization of consumption, restriction of consumption, collaborative consumption, consumer boycotts. 